\title{
Efficacy of Extended Valganciclovir Prophylaxis in Preventing Cytomegalovirus Infection in Pediatric Kidney Transplantation
}

\author{
Faris Hashim ${ }^{1}$, Jon A. Gregg ${ }^{2}$ and Vikas R. Dharnidharka ${ }^{*}, 1$
}

Divisions of ${ }^{1}$ Pediatric Nephrology and ${ }^{2}$ Transplant Nephrology, University of Florida College of Medicine, Gainesville, FL USA

\begin{abstract}
Cytomegalovirus (CMV) is one of the most frequent opportunistic infection in renal transplant (RTx) recipients. Valganciclovir (VGC) has been showed to be safe and highly effective in prophylaxis of CMV infection in RTx recipients. Recently, an increase in delayed onset CMV disease has been noted with some arguing that longer prophylaxis may decrease the late-onset disease.

We retrospectively tested the hypothesis that extended term prophylaxis (ETP) of VGC for 12 months is more effective than short term prophylaxis (STP) of 6 months in preventing CMV infection and disease in pediatric RTx performed at the University of Florida from July 2003 to December 2010. In this period, all recipients underwent prospective CMV PCR (Polymerase Chain Reaction) monitoring and were maintained on similar immunosuppression.

Eighty six patients received RTx during that period. All eligible subjects had to have at least 12 months of graft survival and 18 months of follow up, leaving 73 eligible subjects in final study group. CMV infection or disease occurred in 6/29 (20\%) in the STP group vs 6/44 (14\%) in the ETP group with no statistical significant difference $(\mathrm{P}=0.42)$. Donor positive/recipients negative CMV serology status (D+/R-) were associated with a higher risk of CMV infection in both univariate and multivariate analysis $(\mathrm{P}=0.01)$. Anemia and Leucopenia directly associated with VGC were similar in both groups $(\mathrm{P}=0.58$ and $\mathrm{P}=0.2$ respectively). Biopsy-proven acute rejection was also non-significant in both groups $(\mathrm{P}=0.39)$.

Although ETP for CMV from 6 months to 12 months is safe and has minimal adverse effect, it did not reduce CMV infection or disease. Further controlled studies in pediatrics age group are considered to compare longer versus shorter periods of prophylaxis and their impact on prevention of CMV infection, resistance, cost, and toxicity.
\end{abstract}

Keywords: Late onset CMV infection, renal transplant, short term and long term prophylaxis, valgancyclovir.

\section{INTRODUCTION}

The more potent immunosuppressive therapy that has successfully reduced the incidence of acute rejection, has also resulted in a higher incidence of viral infection [1]. In the pediatric RTx population, infections have replaced rejection as the leading cause of hospitalization [2]. CMV is one of the most important infections in RTx recipients, exposure to the virus increases with age in the general population and is present in more than two-thirds of donors and recipients prior to transplantation [3]. CMV can cause either CMV disease (fever, malaise and cytopenia) or subclinical viral infection usually in the first year post solid organ transplant [4]. CMV may also increase the risk for other opportunistic infections, rejection, and long-term allograft dysfunction $[1,5]$.

Prevention and treatment of CMV primary infection or reactivation has become increasingly important in the management of this patient population. More recently, VGC has become the standard drug used for prophylaxis against

*Address correspondence to this author at the Division of Pediatric Nephrology, Washington University School of Medicine, Campus Box 8116, Room NWT 10-119, 660 South Euclid Avenue, St Louis MO 63110, Tel: 314-286-1574; Fax: 314-286-1149;

E-mail: Dharnidharka_V@kids.wustl.edu
CMV infection [6]. Currently, two different strategies are commonly used to prevent this disease in adult patients: prophylaxis; which is administered during the first 3-6 months following transplant for CMV D+/R- and CMV R+ with no prophylaxis is recommended for CMV D-/R-, or preemptive therapy, which is commenced as soon as viremia is detected through periodical laboratory tests. Since the introduction of these two strategies, an increase in the incidence of late-onset CMV disease has been noted [7, 8].

The IMPACT study is the largest study to demonstrate the effectiveness of prolonging prophylaxis from 3 to 6 months in adult RTx recipients in improving CMV disease up to 12 months post-transplant. Other recent supportive studies performed in adult lung transplant recipients, demonstrated that 12 months of $\mathrm{CMV}$ prophylaxis is beneficial compared to 3 months [9-11].

Although adult and pediatric patients share similar risk factors for developing post RTx CMV disease, the pediatric population has a higher frequency of high-risk patients given the greater proportion of recipients with negative CMV serology to seropositive donors. Despite this situation, very few studies have been carried out in children, and management strategies are for the most part based on results from the adult population $[12,13]$. Only one pediatric study so far showed that 24 weeks of prophylaxis was associated 
with a lower rate of late onset disease than previous reports with 12 weeks regimens, the prolong treatment was also safe and without a significant increase in toxicity and resistance [14].

\section{METHODS}

After approval by the University of Florida Institutional Review Board, we retrospectively evaluated the electronic records for Pediatric RTx recipients between the ages of one to 18 years who underwent RTx at Shands/UF between July 1, 2003 and December 31, 2010. All eligible subjects had to have at least 6 months of graft survival and 18 months of follow up, otherwise those cases were censored out. Data collected from both groups include demographics, immunosuppressive, VGC duration, CMV disease, acute rejection, and hematologic adverse events.

At our center most recipients received induction therapy with rabbit anti-thymocyte globulin (Thymoglobulin, Genzyme, Cambridge, Massachusetts, USA; daily doses of $1.5 \mathrm{mg} / \mathrm{kg} /$ day for 3 days with total dose of $7.5 \mathrm{mg} / \mathrm{kg}$ ). Maintenance medication included calcineurin inhibitor (tacrolimus or cyclosporine) with the dosing adjusted according to the whole blood trough level, mycophenolate mofetil (MMF $600 \mathrm{mg} / \mathrm{m} 2$ twice daily standard pediatric dose and $750 \mathrm{mg} / \mathrm{m} 2$ twice daily for AA children). In case we used mycophenolate sodium $400 \mathrm{mg} / \mathrm{m} 2$ were used. Delayed graft function was defined as hemodialysis within one week post kidney transplant. Prophylactic valganciclovir hydrochloride (Valcyte; Hoffmann-La Roche, New Jersey, USA) was given at a dose of $10-12 \mathrm{mg} / \mathrm{kg} /$ day max $900 \mathrm{mg}$. The dose was adjusted according to the calculated glomerular filtration rate (GFR) by Schwartz equation. All recipients were given VGC for either 6 months STP or 12 months ETP after RTx. If a patient required thymoglobulin for treatment of rejection after the time of prophylaxis, an additional 3 months of prophylactic VGC administration post thymoglobulin was given.

Surveillance for CMV infection was done with PCR once monthly for the first 12 months post RTx. All PCR assays were performed at Shands hospital clinical laboratories. Any level of detection was considered positive. Confirmation of CMV infection was defined by detection of CMV PCR in plasma on 2 consecutive positive plasma samples within 2 weeks and we considered disease to be present when the virus detection was supplemented by viral syndrome including fever $>38 \mathrm{c}^{\circ}$, myalgias, and arthalgias with or without accompanying symptoms of specific organ involvement (hepatitis, pneumonitis, colitis or meningoencephalitis). Treatment of symptomatic infection was done with intravenous (IV) ganciclovir 5-6 mg/kg given every 12 to 24 hours for 2 weeks and for asymptomatic infection is by using a treatment dose of VGC 15 to $18 \mathrm{mg} / \mathrm{kg}$ given orally twice daily for 2 weeks and then keep the patient on prophylactic dose for an extra coarse of 3 months. Anemia was defined as hemoglobin $<10 \mathrm{~g} / \mathrm{dl}$ and leukopenia as white blood cells count $<3000$ cell $/ \mathrm{mcL}$. Acute rejection was defined as biopsy-proven rejection, acute cellular rejection treated with IV methylprednisolone or thymoglobulin depending on the severity.

\section{Statistical Analysis}

Recipients' demographics and clinical events were identified by reviewing medical records, clinical transplant databases, clinical laboratory data, and pathology reports. Data were entered to SAS Statistic software, version 9.3 (Cary, NC, USA). Results are expressed as proportion (\%) or mean (standard deviation; SD). Analyses were performed with Chi-Square testing for categorical variables (Fischer's exact tests as appropriate) and student's t-test for continuous variables (Mann-Whitney test was used for non-normally distributed variables), respectively.

Time to CMV viremia was calculated as the time between transplant and laboratory confirmation of CMV Viremia. Statistical significance for univariate comparisons was defined as $\mathrm{p}<0.05$. Multivariate stepwise logistic regression models were fitted to study the adjusted relationship between the CMV infection and several covariates including risk group, gender, RTx type, induction medication and graft function.

\section{RESULTS}

One thousand and thirty-two blood samples were drawn from 86 patients who received RTx from July 2003 to December 2010. All eligible patients had to have at least 12 months of graft survival and 18 months of follow up, leaving 876 samples from 73 eligible patients in the final study group. Median age at Rtx was 12 years (range 1-17 yrs) in the STP group and 11 years (range 2-17 yrs) in ETP group. Median duration of VGC use in the STP group was 6 months (range 6-7) and 12 months (range 11-13) in the ETP group. As expected, 41/68 (60\%) of donors (5 missing cases) and $30 / 73(41 \%)$ of recipients were seropositive pre transplant, a total of 30 patients $(41 \%)$ were considered at high risk $(\mathrm{D}+/ \mathrm{R}-)$ for CMV infection (30\% from ST vs $51 \%$ ET group).

Notable features of the differences in the demographic feature in this population include longer duration of VGC prophylaxis in those with delayed graft function and positive CMV serostatus. Detail of patient demographics in both groups and donor (D)/recipient (R) CMV serostatus were summarized in Table $\mathbf{1}$.

During the study period, CMV viremia or disease occurred in 6/29 (21\%) in the ST group vs 6/44 (14\%) in the in the ET group $(\mathrm{P}=0.42)$, Table 2 . One recipient from each group developed systemic CMV while they were on prophylaxis and responded well to the IV ganciclovir treatment for 2 weeks with improving of symptoms and gradual disappearance of viremia. No grafts were lost to systemic CMV disease. All asymptomatic infection also responded well to 2 weeks of treatment dose of VGC and no resistance was reported to therapeutic oral VGC despite previous prophylaxis.

Being in the high risk CMV serology group (D+R-) was associated with a significantly higher risk for CMV infection or disease in both groups (Table $\mathbf{3}$ ). This is also confirmed in a multivariate logistic regression model (Table 4). Anemia, 
Table 1. Demographic and clinical characteristic, by treatment group.

\begin{tabular}{|c|c|c|c|}
\hline $\begin{array}{c}\text { Demographic Variable } \\
\text { Total No.73 }\end{array}$ & $\begin{array}{l}\text { STP (6 Months) } \\
\quad \mathrm{N}=29(40 \%)\end{array}$ & $\begin{array}{c}\text { ETP (12 Months) } \\
N=44(60 \%)\end{array}$ & P Value \\
\hline $\begin{array}{l}\text { Average age group, } n \text { (\%) } \\
0-<6 \mathrm{yr} \\
6-<12 \mathrm{yr} \\
12-<18 \mathrm{yr}\end{array}$ & $\begin{array}{l}4(14 \%) \\
7(24 \%) \\
18(62 \%)\end{array}$ & $\begin{array}{l}6(14 \%) \\
17(39 \%) \\
21(48 \%)\end{array}$ & 0.40 \\
\hline $\begin{array}{l}\text { Gender, } \boldsymbol{n}(\%) \\
\text { Male } \\
\text { Female }\end{array}$ & $\begin{array}{l}20(69 \%) \\
9(31 \%)\end{array}$ & $\begin{array}{l}28(64 \%) \\
16(36 \%)\end{array}$ & 0.60 \\
\hline $\begin{array}{l}\text { Race, } \boldsymbol{n}(\%) \\
\text { White } \\
\text { African-American } \\
\text { Others }\end{array}$ & $\begin{array}{l}13(45 \%) \\
13(45 \%) \\
3(10 \%)\end{array}$ & $\begin{array}{l}31(70 \%) \\
12(27 \%) \\
1(3 \%)\end{array}$ & 0.24 \\
\hline $\begin{array}{l}\text { Induction, } \boldsymbol{n}(\%) \\
\text { Thymoglobulin } \\
\text { Simulect } \\
\text { Others }\end{array}$ & $\begin{array}{l}21(72 \%) \\
1(3 \%) \\
7(24 \%)\end{array}$ & $\begin{array}{l}33(75 \%) \\
3(7 \%) \\
8(20 \%)\end{array}$ & 0.49 \\
\hline $\begin{array}{l}\text { Recipient CMV serology, } \boldsymbol{n} \text { (\%) } \\
\text { Positive } \\
\text { Negative } \\
\text { Donor CMV serology, } \boldsymbol{n}(\%) \\
\text { Positive } \\
\text { Negative } \\
\text { Missing }\end{array}$ & $\begin{array}{l}12(41 \%) \\
17(59 \%) \\
13(45 \%) \\
15(52 \%) \\
1(3 \%)\end{array}$ & $\begin{array}{l}18(40 \%) \\
26(59 \%) \\
28(64 \%) \\
12(27 \%) \\
4(9 \%)\end{array}$ & $\begin{array}{l}0.57 \\
0.05\end{array}$ \\
\hline $\begin{array}{l}\text { Graft function post RTx, } \boldsymbol{n}(\%) \\
\text { Immediate GF } \\
\text { Delayed GF }\end{array}$ & $\begin{array}{l}27(93 \%) \\
2(7 \%)\end{array}$ & $\begin{array}{l}32(73 \%) \\
12(27 \%)\end{array}$ & 0.03 \\
\hline $\begin{array}{l}\text { Transplant type, } \boldsymbol{n}(\%) \\
\text { Living donor } \\
\text { Deceased }\end{array}$ & $\begin{array}{l}11(38 \%) \\
18(62 \%)\end{array}$ & $\begin{array}{l}9(20 \%) \\
35(80 \%)\end{array}$ & 0.06 \\
\hline $\begin{array}{l}\text { Rejection, } \boldsymbol{n}(\%) \\
\text { Yes } \\
\text { No }\end{array}$ & $\begin{array}{l}2(7 \%) \\
27(93 \%)\end{array}$ & $\begin{array}{l}8(18 \%) \\
36(82 \%)\end{array}$ & 0.17 \\
\hline
\end{tabular}

Table 2. Details of CMV infection by treatment groups.

\begin{tabular}{|l|l|l|l|}
\hline \multicolumn{1}{|c|}{$\begin{array}{c}\text { Demographic Variable } \\
\text { Total No.73 }\end{array}$} & \multicolumn{1}{|c|}{$\begin{array}{c}\text { STP (6 Months) } \\
\text { N=29 (40\%) }\end{array}$} & $\begin{array}{c}\text { ETP (12 Months) } \\
\text { N= 44 (60\%) }\end{array}$ \\
\hline CMV infection, $n$ (\%) & $\begin{array}{l}\text { P Value } \\
\text { Yes } \\
\text { No }\end{array}$ & $\begin{array}{l}6(14 \%) \\
38(86 \%)\end{array}$ & $\mathbf{0 . 4 2}$ \\
\hline
\end{tabular}

leucopenia and biopsy proven acute rejections were not significant in both groups (Table 5).

\section{DISCUSSION}

CMV continues to be an important cause of morbidity and mortality in children who have received RTx. Children have an increased likelihood of acquiring primary CMV infection because they are more often CMV negative at the time of surgery. However, the duration of prophylaxis is still an area of debate. Consensus recommendations guide the duration of therapy and have recommended 3-6 months of prophylaxis based on the serostatus of the donor and recipient $[15,16]$.

Despite many studies focusing on the pediatric organ transplant population, standard protocols for CMV 
Table 3. CMV serology and CMV infection by treatment group infection.

\begin{tabular}{|l|c|c|c|}
\hline \multicolumn{1}{|c|}{ Positive CMV Serology } & STP (6 Months) & ETP (12 Months) & Fisher's Exact Test \\
\hline \hline High Risk Group (D+/R-) & $3 / 6(50 \%)$ & $6 / 6(100 \%)$ & 0.01 \\
Intermediate and low Risk (D+/R+ \& D-/R+) & $3 / 6(50 \%)$ & $0 / 6(0 \%)$ & \\
\hline
\end{tabular}

monitoring and administering antiviral therapies are not established in this population [17-20]. In 2011, CamachoGonzalez, et al. showed that prolonging VGCV prophylaxis to 6 months is safe and decreases the incidence of late onset CMV disease without a significant increase in toxicity and resistance [14]. However, the study was limited because of the fact that they did not have a control group. Our study is the first study to compare the efficacy of prolonged (12 moths) VGC prophylaxis in preventing CMV infection and disease in the pediatric RTx population.

Table 4. Logistic model for the CMV infection.

\begin{tabular}{|c|c|}
\hline Predictor Variable & P Value \\
\hline Prophylactic VGC & 0.42 \\
\hline High risk group(D+R-) & 0.01 \\
\hline Gender & 0.56 \\
\hline Tx type & 0.80 \\
\hline Induction medication & 0.43 \\
\hline Graft function & 0.41 \\
\hline
\end{tabular}

Strict cut-off values of CMV PCR indicating need of therapeutic intervention are not available. Values around $1000-2000 \mathrm{IU} / \mathrm{mL}$ have been suggested [21, 22]. Our hospital policy is to consider any level of detection as positive which will increase the sensitivity of the test. Despite that, our data revealed an overall rate of $\mathrm{CMV}$ infection of $16 \%$ (21\% from ST group versus $14 \%$ from ET group). These results are lower than what has been reported in other previous pediatric studies with less duration of prophylaxis [8, 14, 18, 23]. Humar et al. in their prospective randomized controlled trial showed a cumulative incidence of $21 \%$ in adult RTx recipient who received 200 days of VGC prophylaxis [9]. However, no real comparisons can be made between our study and this study as they are completely different in the design and prophylactic approach.

Our results did not show any significant difference between the ETP and STP in reducing the CMV infection and disease $(\mathrm{P}=0.42)$. Nevertheless, the multivariate logistic regression model has been showed (in accord with prior studies) that CMV serology group (D+/R-) was associated with significantly higher risk for developing CMV infection or disease in both group $(\mathrm{P}=0.01)[9,14,23,24]$.

None of our patients who developed CMV infection during prophylaxis were unresponsive to therapy with oral VGC or IV ganciclovir despite previous prophylaxis which indicate less risk of developing drug resistance despite the prophylaxis therapy. Lastly, we did not observe significant differences in presumed treatment related adverse events between the two treatment groups. This signifies the safety of $\mathrm{VGC}$ as a prophylaxis treatment in renal $\mathrm{Tx}$ pediatric population, similar to results from several previous studies $[14,25]$

To summarize, our results demonstrate that although a 12-month regimen of oral VGC was a safe approach for long-term prevention of CMV infection in RTx pediatric recipients, it did not show a significant difference compared with 6 months of therapy.

\section{LIMITATION}

Although our study was limited because of its retrospective nature and the fact of the small sample size comparing to the adult studies, it's the only study that evaluated the efficacy and safety of 12 months VGC prophylaxis comparing to the other strategy in RTx pediatric patients. In addition, the study was a single center study which might limit the generalizability of the study result.

Table 5. VGC side effects and acute rejection by treatment group.

\begin{tabular}{|c|c|c|c|}
\hline Total No. 73 & $\begin{array}{c}\text { STP Group (6 Months) } \\
29(40 \%)\end{array}$ & $\begin{array}{c}\text { ETP Group (12 Months) } \\
44(60 \%)\end{array}$ & P Value \\
\hline $\begin{array}{l}\text { Anemia } \\
\text { Yes } \\
\text { No }\end{array}$ & $\begin{array}{c}6(21 \%) \\
23(79 \%)\end{array}$ & $\begin{array}{c}8(18 \%) \\
36(82 \%)\end{array}$ & 0.58 \\
\hline $\begin{array}{l}\text { Leukopenia } \\
\text { Yes } \\
\text { No }\end{array}$ & $\begin{array}{c}2(7 \%) \\
27(93 \%)\end{array}$ & $\begin{array}{c}7(16 \%) \\
37(84 \%)\end{array}$ & 0.20 \\
\hline $\begin{array}{l}\text { Rejection post RTx } \\
\text { Yes } \\
\text { No }\end{array}$ & $\begin{array}{c}5(17 \%) \\
24(83 \%)\end{array}$ & $\begin{array}{c}8(18 \%) \\
36(82 \%)\end{array}$ & 0.39 \\
\hline
\end{tabular}


Multicenter, randomized, clinical studies involving several pediatric transplant centers are needed to help better define optimal duration of CMV prophylaxis in the pediatric age group.

\section{AUTHOR CONTRIBUTIONS}

Faris Hashim: participated in research design, participated in performance of research, writing of paper.

Jon A. Gregg: participated in research design, data analysis.

Vikas Dharnidharka: participated in research design, performance of research data analysis, writing of paper.

\section{ABBREVIATIONS}

CMV $=$ Cytomegalovirus
RTx $=$ Renal Transplant
STP $=$ Short term prophylaxis
ETP $=$ Extended term prophylaxis
VGC $=$ Valganciclovir
PCR $=$ Polymerase chain reaction

\section{CONFLICT OF INTEREST}

The authors confirm that this article content has no conflict of interest.

\section{ACKNOWLEDGEMENTS}

This work was presented as an abstract (abstract published in AJKD Vol.61 issue 4, page B45) at the National Kidney Foundation meeting in April 2013.

Dr. Hashim was also partially supported for this work through the University of Florida's Advanced Post-Graduate Program in Clinical Investigation, funded through National Institutes of Health (NIH)/National Clinical and Translational Science (NCATS) CTSA grant UL1TR000064.

\section{REFERENCES}

[1] Fishman JA, Rubin RH. Infection in organ-transplant recipients. N Engl J Med 1998; 338(24): 1741-51.

[2] Dharnidharka VR, Stablein DM, Harmon WE. Post-transplant infections now exceed acute rejection as cause for hospitalization: a report of the NAPRTCS. Am J Transplant 2004; 4(3): 384-9.

[3] Rubin RH. Infectious disease complications of renal transplantation. Kidney Int 1993; 44(1): 221-36.

[4] Sia IG, Patel R. New strategies for prevention and therapy of cytomegalovirus infection and disease in solid-organ transplant recipients. Clin Microbiol Rev 2000; 13(1): 83-121, table of contents.

[5] Fijo-Lopez-Viota J, Espinosa-Roman L, Herrero-Hernando C, Sanahuja-Ibanez MJ, Vila-Santandreu A, Praena-Fernandez JM. Cytomegalovirus and paediatric renal transplants: is this a current issue? Nefrologia 2013; 33(1): 7-13.

[6] Paya C, Humar A, Dominguez E. Efficacy and safety of valganciclovir vs. oral ganciclovir for prevention of cytomegalovirus disease in solid organ transplant recipients. Am J Transplant 2004; 4(4): 611-20.

[7] Cervera C, Pineda M, Linares L. Impact of valganciclovir prophylaxis on the development of severe late-cytomegalovirus disease in high-risk solid organ transplant recipients. Transplant Proc 2007; 39(7): 2228-30.

[8] Arthurs SK, Eid AJ, Pedersen RA, Kremers WK, Cosio FG, Patel R, Razonable RR. Delayed-onset primary cytomegalovirus disease and the risk of allograft failure and mortality after kidney transplantation. Clin Infect Dis 2008; 46(6): 840-6.

[9] Humar A, Lebranchu Y, Vincenti F, Blumberg EA, Punch JD, Limaye AP, Abramowicz D, Jardine AG, Voulgari AT, Ives J, Hauser IA, Peeters P. The efficacy and safety of 200 days valganciclovir cytomegalovirus prophylaxis in high-risk kidney transplant recipients. Am J Transplant 2010; 10(5): 1228-37.

[10] Humar A, Limaye AP, Blumberg EA, Hauser IA, Vincenti F, Jardine AG, Abramowicz D, Ives JA, Farhan M, Peeters P. Extended valganciclovir prophylaxis in D+/R- kidney transplant recipients is associated with long-term reduction in cytomegalovirus disease: two-year results of the IMPACT study. Transplantation 2011; 90(12): 1427-31.

[11] Palmer SM, Limaye AP, Banks M, Gallup D, Chapman J, Lawrence EC, Dunitz J, Milstone A, Reynolds J, Yung GL, Chan KM, Aris R, Garrity E, Valentine V,McCall J, Chow SC, Davis $\mathrm{RD}$, Avery R. Extended valganciclovir prophylaxis to prevent cytomegalovirus after lung transplantation: a randomized, controlled trial. Ann Intern Med 2010; 152(12): 761-9.

Martin JM, Danziger-Isakov LA. Cytomegalovirus risk, prevention, and management in pediatric solid organ transplantation. Pediatr Transplant 2011; 15(3): 229-36.

Comoli P, Ginevri F. Monitoring and managing viral infections in pediatric renal transplant recipients. Pediatr Nephrol 2011; 27(5): 705-17.

Camacho-Gonzalez AF, Gutman J, Hymes LC, Leong T, Hilinski JA. 24 weeks of valganciclovir prophylaxis in children after renal transplantation: a 4-year experience. Transplantation 2011; 91(2): 245-50.

[15] Chapman JR. The KDIGO clinical practice guidelines for the care of kidney transplant recipients. Transplantation 2010; 89(6): 644-5.

[16] Kotton CN, Humar A, Caliendo AM, Lautenschlager I, Preiksaitis J, Kumar D, Abate D, Emery V, Khanna R, Lilleri D, Manuel O, Sester M, Humar A,Kotton CN, Blumberg E, Camargo LF, Gordon C, Huprikar S, Kamar N, Lattes R, Merville P, Mueller N, Paget G, Reischig T, Singh N, Snydman DR,Torre-Cisneros J, Westall G, Zamora M, Asberg A, Harrison J, Morris M, Munoz $\mathrm{P}$, Rawlinson W, Chou S, Alain S, Baldanti F, Limaye AP, Lurain N,Danziger-Isakov L, Allen U, Green M, Herold BC, Michaels M. Updated international consensus guidelines on the management of cytomegalovirus in solid-organ transplantation. Transplantation 2013; 96(4): 333-60.

[17] Lapidus-Krol E, Shapiro R, Amir J, Davidovits M, Steinberg R, Mor E, Avitzur Y. The efficacy and safety of valganciclovir vs. oral ganciclovir in the prevention of symptomatic CMV infection in children after solid organ transplantation. Pediatr Transplant 2010; 14(6): 753-60.

[18] Renoult E, Clermont MJ, Phan V, Buteau C, Alfieri C, Tapiero B. Prevention of $\mathrm{CMV}$ disease in pediatric kidney transplant recipients: evaluation of pp67 NASBA-based pre-emptive ganciclovir therapy combined with CMV hyperimmune globulin prophylaxis in high-risk patients. Pediatr Transplant 2008; 12(4): 420-5.

[19] Danziger-Isakov LA , Worley S, Michaels MG, Arrigain S, Aurora P, Ballmann M, Boyer D , Conrad C, Eichler I,Elidemir O, Goldfarb S, Mallory GB, Mogayzel PJ, Parakininkas D, Solomon $\mathrm{M}$, Visner G , Sweet S, and Faro A. The risk, prevention, and outcome of cytomegalovirus after pediatric lung transplantation. Transplantation 2009; 87(10): 1541-8.

[20] Madan RP, Campbell AL, Shust GF, Kahn AR, Wistinghausen B, Posada R, Kerkar N, Shneider BL, Emre S, Herold BC. A hybrid strategy for the prevention of cytomegalovirus-related complications in pediatric liver transplantation recipients. Transplantation 2009; 87(9): 1318-24.

[21] Smith JM, Dharnidharka VR. Viral surveillance and subclinical viral infection in pediatric kidney transplantation. Pediatr Nephrol 2014

[22] Reischig T, Hribova P, Jindra P, Hes O, Bouda $\quad M$, Treska V, Viklicky O. Long-term outcomes of pre-emptive valganciclovir compared with valacyclovir prophylaxis for prevention of cytomegalovirus in renal transplantation. J Am Soc Nephrol 2012; 23(9): 1588-97. 
[23] Helanterä I, Kyllönen L, Lautenschlager I, Salmela K, Koskinen P. Primary CMV infections are common in kidney transplant recipients after 6 months valganciclovir prophylaxis. Am J Transplant 2010; 10(9): 2026-32.

[24] Helantera I, Lautenschlager I, Koskinen P. Prospective follow-up of primary $\mathrm{CMV}$ infections after 6 months of valganciclovir prophylaxis in renal transplant recipients. Nephrol Dial Transplant 2009; 24(1): 316-20.
[25] Zafrani L, Truffaut L, Kreis H, Etienne D, Rafat C, Lechaton S, Anglicheau D, Zuber J, Ciroldi M, Thervet E, Snanoudj R, Mamzer MF, Martinez F, Timsit MO,Bergougnoux L, Legendre C. Incidence, risk factors and clinical consequences of neutropenia following kidney transplantation: a retrospective study. Am J Transplant 2009; 9(8): 1816-25.

(C) Hashim et al.; Licensee Bentham Open

This is an open access article licensed under the terms of the Creative Commons Attribution Non-Commercial License (http://creativecommons.org/licenses/by-nc/3.0/) which permits unrestricted, non-commercial use, distribution and reproduction in any medium, provided the work is properly cited. 